\title{
Impact of Physical Learning Environment on Students' Learning Outcomes in Secondary Schools in Lagos State, Nigeria
}

\author{
Abraham Owoseni, ${ }^{1, *}$ Eziyi Ibem², Akunnaya Opoko' \\ ${ }^{1}$ Department of Architecture, Covenant University, Nigeria \\ ${ }^{2}$ Department of Architecture, Faculty of Environmental Sciences, University of Nigeria, Nigeria
}

Received May 14, 2020; Revised June 11, 2020; Accepted July 20, 2020

Copyright $\subseteq 2020$ by authors, all rights reserved. Authors agree that this article remains permanently open access under the terms of the Creative Commons Attribution License 4.0 International License

\begin{abstract}
The classroom is the physical learning environment where learning takes place in formal education. More worrisome globally is the need for classroom learning spaces that can improve students' learning outcomes not just in one aspect of learning outcome but holistically: affective, behavioural and cognitive domains. In achieving this, this paper draws data from findings of a study carried out to investigate the impact of the classroom learning environment on students' learning outcomes. Quantitative data were collected on 37 variables from students across the three senatorial districts in Lagos State, Nigeria's commercial capital with the highest number of schools. Multi-stage sampling technique was adopted using a hybrid of three techniques: purposive, quota and random sampling to select the approved schools, group them in quota and final selection of respondents respectively. A total of 674 copies of the questionnaire were administered by hand during the first term of the 2018/2019 academic session. A total of 488 were analysed using descriptive statistics, factor analysis and regression analysis. The result identified eleven (11) significant factors to consider in remodelling classroom learning spaces in order to improve students' learning outcomes. As a result of these factors, a combined proportion of $53.6 \%$ of respondents experienced a significant impact on the classroom physical learning environment on their learning outcomes. 31.8\% affirmed to its average impact while only $6.9 \%$ averred to its least impact, respectively. This paper provides a focus for Architects, interior designers, space planners and other stakeholders in the educational planning and management on the guidelines for remodelling classroom spaces to holistically improve students' learning outcomes.
\end{abstract}

Keywords Classroom, Classroom Spaces, Learning, Learning Outcomes, Remodelling, Secondary Schools

\section{Introduction}

Globally, quality education has been seen as the principal agent for personal and national transformation, and thus there is a growing yearning for the improvement of educational deliverables across the world. With education, crude talents and abilities are refined into skills and manpower required for a productive society. As such, all countries strive to achieve quality education in pursuits of goal four of the Sustainable Development Goals (SDGs). In line with this, most governments and educational agencies have continued to invest in physical facilities that accommodate various spaces such as classrooms, library, laboratories and offices in schools.

In a developing country like Nigeria with a rapidly growing population and education is one of the largest sectors of the national economy, the existing number of schools is grossly inadequate, while additional classroom blocks are being added to existing school buildings to cater for the needs of new intake of the schools. In all these, there is a concern about the capacity of the existing schools to provide adequate support for the ABCs of learning [1]. In this context, the ABCs of learning refers to the affective, behavioural and cognitive development of learners. Similarly, the issue of quality in education is not isolated to curriculum design alone or subject content but also includes the design of the learning environment and adjoining school factors [2].

The physical learning environment contains physical sensory elements such as colour, lighting, space, social and furniture, which define the place where learners learn. Whilst students are expected to perform well in standardised tests and exams, which is their cognitive 
development, they are also expected to develop 21st century skills such as team work, collaboration, critical thinking amongst others. These skills are categorised under the affective development of students. Also, they are expected to be well comported and behaved in class. The various aspects of a classroom affect students learning outcomes; from lighting, to noise control, ventilation, colours, furniture amongst others. Notably, previous studies [3]-[9] have largely focused on individual aspects such as noise levels, indoor air quality, colour, furniture arrangement whilst also considering students' individual attributes. Based on the above, Al-Enezi [10] has observed that very little research effort has gone into the examination of the impact these components of physical learning environment have on students learning outcomes, particularly as it relates to the ABCs of learning. It is also important to note that from the review of published literature, it was found that most of the existing studies on this subject are focused on the situation in developed countries in Europe and America and emerging countries in South East Asia, while studies within the context of countries in sub-Saharan Africa are underrepresented in the literature.

In view of the foregoing, the aim of this study was to investigate the extent to which classroom physical learning environment impact on students' learning outcomes in selected secondary schools in Lagos State, Nigeria. This is with a view to making suggestions on how best to remodel classrooms to improve learning outcomes. The study was guided by two main research objects: (1) To identify the components of the physical classroom environments as perceived by students in selected secondary schools in Lagos, State, Nigeria (2) To examine the impacts of the physical classroom environment on the affective, behavioural and cognitive (ABC) development of the student in the study area.

Lagos State, Nigeria was chosen for this research because it is the commercial capital with the highest number of secondary schools in Nigeria.

\section{Review of Literature}

This section is a review of published literature on classrooms, learning spaces and learning outcomes of students.

\subsection{Classroom Learning Environment}

Students spend a large part of school time in the school's learning environment, especially in their classrooms. The learning environment is capable of stimulating students to engage in the learning process, influencing the behaviour of students and assisting the development of their skills or cognitive perception [11]. In learning, students talk about what is being learnt, then engage with it, writing about it, and relating it with experiences from the past whilst applying the learning points to daily lives [12].

Several components make up the physical learning environment of the classrooms. The physical fabric of a school affects the various activities and how they play out. Architecture plays a key role in shaping indoor and outdoor spaces and the physical ambience. Some of the components of the learning environment identified in the literature include physical sensory elements like colour, lighting, space and furniture for the learning space [13]. Others are lighting, air quality/ventilation, temperature/ thermal comfort, acoustics/noise level, nature and adjoining outdoor views, furniture and its arrangement in the classroom environment, technology/ Information and Communications Technology (ICT) facilities, objects and décor and colour.

While some exert more impact than the other, a blend of these components is required in a classroom environment. In a similar study [14], around $54.5 \%$ of college respondents emphasised furniture arrangement and other physical conditions as key components of the learning environment. Arising from this, both public schools and private schools make good attempts to provide these components. However, a previous study [15] has shown that a sizeable portion of the infrastructure in the public secondary schools in this part of Nigeria is in a state of disrepair and require a high level of maintenance work to make them effectively support students' learning process.

\subsection{Learning and Learning Outcomes}

The impact of learning could result in outcomes that affect knowledge, skills, actions, feelings and emotions, ideas, affiliation to learning, a sense of oneself, a sense of others, and a sense of membership [16]. The impact of learning is not short-lived; it is long term. However, in the short term, certain rubrics can be used to measure learning outcomes. Examples include class attendance, formative assessments and general engagement and interactions in class and learning activities. These outcomes can be further grouped into affective, behavioural \& cognitive indicators [17]. Affective can be described as learners' engagement in class. This deals with the way a learner shows feelings and emotions and how he/she participates in class activities and conversation. It also includes team/group work, collaboration and general class interaction. The behavioural (i.e. learners' behaviour in class) is concerned with the way a learner demonstrates reflex actions, physical/psychomotive functions and movements in class. This could be positive or negative, and when positive, students are well comported, and when negative, they are given disciplinary verdicts as a result of negative acts such as an act of vandalism or lateness to school or general class disruption. The cognitive aspect, 
which is students' academic performance in class, is a demonstration of knowledge, comprehension, application, analysis, and synthesis. This is measured through the standardised test scores and exams coupled with teacher observation. From the review of literature, a total of 37 variables representing various components of the classroom physical learning environment that affects learning outcomes were identified and mapped with the specific domains of learning outcomes they majorly impact on. The summary is as presented in Table 1.

Table 1. Components of the classroom physical learning environment and the respective domain of learning outcomes they impact

\begin{tabular}{|c|c|c|}
\hline & Components of Classroom Physical Environment & Most Impacted Learning Outcome \\
\hline 1 & Interactive arrangement of desks and seats for collaboration and teamwork & \multirow{4}{*}{ Affective } \\
\hline 2 & Interactive arrangement of desks and seats for social interaction & \\
\hline 3 & Engaging wall posters and plants in class & \\
\hline 4 & Good view to outdoor nature & \\
\hline 5 & Accessible lighting and electrical controls & \multirow{22}{*}{ Behavioural } \\
\hline 6 & Adequate ventilation in the classroom & \\
\hline 7 & Conducive classroom through the fresh air & \\
\hline 8 & Large open-able windows in the classroom & \\
\hline 9 & Obstruction to ventilation / free air circulation & \\
\hline 10 & Good landscape and outdoor element in school & \\
\hline 11 & Comfortable classroom desks and seats & \\
\hline 12 & Inspiring wall decorations in the classroom & \\
\hline 13 & General colour combinations in the classroom & \\
\hline 14 & Interior classroom wall colours & \\
\hline 15 & Motivation to come to class through colours in the classroom & \\
\hline 16 & $\begin{array}{l}\text { Neat and orderly classroom through the provision of lockers and adequate storage } \\
\text { spaces }\end{array}$ & \\
\hline 17 & Overcrowded classroom & \\
\hline 18 & Adequate classroom size & \\
\hline 19 & Adequate power supply (electricity) to the classroom & \\
\hline 20 & Adequate waste bins in the classroom & \\
\hline 21 & General safety in the classroom & \\
\hline 22 & Safety gadgets like fire extinguishers in the classroom & \\
\hline 23 & Safety gadgets like first aid box in the classroom & \\
\hline 24 & Adequate classroom height & \\
\hline 25 & Good classroom shape & \\
\hline 26 & Students' general interest in coming to the classroom every day & \\
\hline 27 & General classroom visibility and illumination & \multirow{11}{*}{ Cognitive } \\
\hline 28 & Visibility to the white/chalkboard & \\
\hline 29 & Obstruction to natural lighting & \\
\hline 30 & Glare control through the use of blinds & \\
\hline 31 & Noise hindering comprehension & \\
\hline 32 & Noise hindering focus & \\
\hline 33 & Audibility in class & \\
\hline 34 & External noise to the class & \\
\hline 35 & Connection to the internet and other internet-based portals in the classroom & \\
\hline 36 & Increase in ICT skills through available ICT facilities & \\
\hline 37 & Exciting \& Interesting Learning through the use of ICT facilities & \\
\hline
\end{tabular}

Source: Compiled by the authors 


\section{Research Methods}

The data presented in this article are drawn from a more extensive research work designed to investigate the impact of classroom architecture on students' learning outcomes in selected secondary schools in Lagos State, Nigeria. The research design and approach used for the study was a cross-sectional survey and quantitative research, respectively. The research population comprised all approved public and private secondary schools in Lagos State, Nigeria, with focus on the senior secondary sections of the schools, with students predominantly late adolescents across the three senatorial districts in the study area namely: Lagos West, Lagos Central and Lagos East.

The multi-stage sampling technique was adopted using a hybrid of three techniques: purposive sampling, quota and random sampling. The purposive sampling was based on the criterion that the selected schools must be approved with a senior secondary section. Next, was the quota sampling, in which the schools were grouped in the three senatorial districts, dividing them into smaller units and afterwards applying a ratio based on their existence. A ratio of 3:1 (private: public schools) was adopted based on proportion of private and public schools, which was found to be 1078 private senior secondary schools and 338 public senior secondary schools, respectively. Lastly, schools were selected at random; three (3) private senior secondary schools and one (1) public senior secondary school per senatorial district in line with the ratio 3:1 already established.

The sample size for the study was drawn from the population of the selected schools. The total number of students enrolled in the selected senior secondary private and public senior secondary schools at the time the research was conducted was $\mathrm{N}=3291$. The sample size formulae for finite population by developed by Yamane, (1967) cited in Singh et al., (2014) [11] shown in equation 1 was applied for population greater than 100 .

$$
n=\frac{N}{1+N(e) 2}
$$

where; $\mathrm{N}=3018$; the total population size (for population above one hundred (100), e = the maximum acceptable error margin (5\% which gives $\mathrm{e}=0.05)$ and, $\mathrm{n}=$ the required sample size. Using this formula, the minimum sample size (n) obtained was 353. However, census was applied for population below 100. In all, a total sample size of 626 was obtained. The data gathering instrument used was principally questionnaire, which was designed and pre-tested by the researchers. It had five (5) sections A to $\mathrm{E}$ focusing on the different thematic issues investigated in the research. However, only data collected from sections A \& $\mathrm{E}$ of the questionnaire were included in this paper. This covered socio-economic characteristics and impact of classroom architecture on students' learning outcomes. In a bid to assess the extent to which the physical learning environment of classrooms influences students' learning outcomes in selected secondary schools in Lagos State, Nigeria, quantitative data were collected on 37 variables as captured in the section $E$ of the research instrument. Prior to this, the Cronbach's Alpha was used to measure the adequacy of the result which gave the Cronbach's Alpha of the 37 items at the value of 0.877 thus affirming the reliability of the instrument.

A total of 674 copies of the questionnaire were administered physically during the first term of the 2018/2019 academic session. The administration of the questionnaires was done during weekdays after due permission has been sought and granted by the relevant government agencies for the public schools and proprietors of the private schools as well as their respective principals. Totally, 488 questionnaires representing around $72 \%$ of the total number administered were duly filled and useful for analysis.

The data collected from the survey were analysed using the Statistical Package for the Social Sciences (SPSS) software package. The two main types of data analyses conducted were principal component analysis (PCA) and Categorical regression analysis (CATREG). The principal component analysis, which is a variant of factor analysis, was used to identify the various dimensions/factors of the physical learning environment with the influence on the students' learning outcomes. Notably, this analysis was carried out on the 37 variables used to investigate this in the schools sampled, as shown in Table 1. Before the PCA was conducted, the suitability of the data for this analysis was investigated. The Kaiser-Meyer-Olkin Measure of Sampling Adequacy (KMO) value was 0.87 , and Bartlett's Test of Sphericity was significant at a value of 0.00 . This implies that the dataset is suitable for PCA. The CATREG analyses were used to investigate the impact of the various components of the classroom environment obtained from the PCA on the affective, behavioural and cognitive domains of the students' learning outcome. In view of this, three different regression analyses were conducted for each domain. In each case, the predictor's variables were the factors identified and presented in Table 2 while the dependent variables were student engagement, student's behavioural tendencies and students' exam/test scores for the affective, behavioural and cognitive learning outcomes, respectively. The results are presented using tables

\section{Results and Discussion}

The results in Table 2 show the various dimensions of the students' learning environment as perceived by them. Based on this result, it is evident that the students understood and interpreted their learning environments in the 11 distinct dimensions (factors 1-11). These dimensions are also the factors known to have significant influence on their learning outcomes. Examination of the 
results in Table 2 reveals that the top three factors identified are classroom comfort, contributing $22.62 \%$ of the variance in 37 variables investigated and with 5 variables loaded on it. This followed by classroom ambience, accounting for $5.95 \%$ of the variance and thereafter, classroom geometry.

Table 2. Factor Analysis of the influence of the physical learning environment of classrooms on students' learning outcomes

\begin{tabular}{|c|c|c|c|}
\hline Factors & $\begin{array}{l}\text { \% Variance } \\
\text { accounted for }\end{array}$ & Variables & $\begin{array}{l}\text { Component } \\
\text { Loadings }\end{array}$ \\
\hline \multirow{6}{*}{$\begin{array}{l}\text { Factor } 1 \\
\text { Classroom Comfort }\end{array}$} & \multirow{6}{*}{22.62} & The fresh air in my class makes the class conducive for learning & .749 \\
\hline & & $\begin{array}{l}\text { There is adequate ventilation in my classroom, conducive enough for } \\
\text { learning }\end{array}$ & .725 \\
\hline & & The size of open-able windows in my classroom is large enough & .621 \\
\hline & & My classroom desks and seats are very comfortable for my learning & .609 \\
\hline & & I hear easily and audibly in the classroom & .492 \\
\hline & & The lighting in my classroom aids good visibility and illumination & .453 \\
\hline \multirow{5}{*}{$\begin{array}{l}\text { Factor } 2 \\
\text { Classroom Ambience }\end{array}$} & \multirow{5}{*}{5.95} & I am happy with the general colour combinations in my classroom & .741 \\
\hline & & I like the colours of the interior walls in my classroom & .680 \\
\hline & & The wall decorations in my classroom inspire me & .657 \\
\hline & & $\begin{array}{l}\text { I am always motivated to come to class because of the colour of the } \\
\text { classroom }\end{array}$ & 641 \\
\hline & & Plants and inspirational posters improve my engagement in class & .536 \\
\hline \multirow{4}{*}{$\begin{array}{l}\text { Factor } 3 \\
\text { Classroom Geometry }\end{array}$} & \multirow{4}{*}{5.82} & The height of my classroom is adequate & .812 \\
\hline & & I am happy with the shape of my classroom & .731 \\
\hline & & My classroom size is adequate & .538 \\
\hline & & I feel safe in the class & .533 \\
\hline \multirow{6}{*}{$\begin{array}{l}\text { Factor } 4 \\
\text { Classroom Safety }\end{array}$} & \multirow{6}{*}{4.59} & There are safety gadgets in the class like fire extinguishers & .795 \\
\hline & & There are safety gadgets in the class like first aid box & .784 \\
\hline & & There is adequate power supply (electricity) to my classroom & .501 \\
\hline & & $\begin{array}{l}\text { I can easily connect to the internet and other internet-based portals in my } \\
\text { classroom }\end{array}$ & .480 \\
\hline & & There are adequate waste bins in my classroom & .458 \\
\hline & & The lighting and electrical controls in my classroom are easily accessible & .405 \\
\hline \multirow{2}{*}{$\begin{array}{l}\text { Factor } 5 \\
\text { ICT } \\
\text { Classroom }\end{array}$} & \multirow[b]{2}{*}{4.12} & ICT facilities in the classroom can increase my ICT skills & .799 \\
\hline & & $\begin{array}{l}\text { The use of ICT facilities by my teachers makes learning exciting and } \\
\text { interesting for me }\end{array}$ & .798 \\
\hline \multirow{3}{*}{$\begin{array}{l}\text { Factor } 6 \\
\text { Classroom Acoustics }\end{array}$} & \multirow{3}{*}{3.93} & Noise hinders my comprehension in class & .835 \\
\hline & & $\begin{array}{l}\text { Noise makes it difficult for me to focus on a particular task in the } \\
\text { classroom }\end{array}$ & .810 \\
\hline & & I hear so much noise from outside during class sessions & .474 \\
\hline \multirow{2}{*}{$\begin{array}{l}\text { Factor } 7 \\
\text { Classroom Furniture }\end{array}$} & \multirow{2}{*}{3.45} & $\begin{array}{l}\text { The type of classroom desks and seats in my class provides opportunity } \\
\text { for social interaction }\end{array}$ & .814 \\
\hline & & $\begin{array}{l}\text { The arrangement of desks and seats in my classroom encourages } \\
\text { collaboration and team work }\end{array}$ & .789 \\
\hline \multirow{3}{*}{$\begin{array}{l}\text { Factor } 8 \\
\text { Classroom Visibility } \\
\text { \& Outdoor Views }\end{array}$} & \multirow{3}{*}{3.20} & $\begin{array}{l}\text { The use of blinds help to control glare from the natural day lighting into } \\
\text { the classroom }\end{array}$ & .415 \\
\hline & & I have a good view from my classroom to outdoor nature & .595 \\
\hline & & $\begin{array}{l}\text { My school has good landscape and outdoor elements like gardens, lawns } \\
\text { and deciduous trees }\end{array}$ & .472 \\
\hline \multirow{2}{*}{$\begin{array}{l}\text { Factor } 9 \\
\text { Obstruction to } \\
\text { Classroom Lighting } \\
\text { \& Ventilation } \\
\end{array}$} & \multirow{2}{*}{3.00} & $\begin{array}{l}\text { There is obstruction to natural lighting into the classroom (such as a } \\
\text { blocked window) }\end{array}$ & .797 \\
\hline & & $\begin{array}{l}\text { There is obstruction to ventilation / free air circulation (such as a blocked } \\
\text { window) }\end{array}$ & .745 \\
\hline $\begin{array}{l}\text { Factor } 10 \\
\text { Classroom Density }\end{array}$ & 2.82 & My classroom is overcrowded & .787 \\
\hline $\begin{array}{l}\text { Factor } 11 \\
\text { Position \& Visibility } \\
\text { of White/Chalkboard }\end{array}$ & 2.78 & I can see the white/chalkboard & .673 \\
\hline
\end{tabular}


Also, the result of the principal component analysis conducted on the 37 items on a 5 point Likert-type scale revealed a correlation coefficient between all the items as not less than 0.40 .

In order to investigate the influence of the physical environment of the classrooms on students' learning outcomes, a regression analysis was conducted where each learning outcome is the dependent variable and the classroom physical environment as the independent variables.

For cognitive development, the classroom physical learning environment has a R2 value of $16 \%$ with significant impact on academic performance with $\mathrm{p}=0.00$. The factors that have most significant impact on students' academic performance are classroom ambience ( $\beta=-.175)$, classroom geometry $(\beta=.157)$, classroom safety $(\beta$ $=.196)$, classroom acoustics $(\beta=-.123)$, Obstruction to Classroom Lighting \& Ventilation $(\beta=-.111)$ and Position \& Visibility of White/Chalkboard $(\beta=.130)$.
For behavioural development, the classroom physical learning environment has a R2 value of $10.2 \%$ with significant impact on students' behavioural tendencies with $\mathrm{p}=0.006$. The factors that have most significant impact on students' behavioural tendencies are classroom geometry $(\beta=-.217)$, classroom acoustics $(\beta=.171)$ and Position of White/Chalkboard ( $\beta=.145)$.

For affective development of students, the classroom physical learning environment has a R2 value of $10.2 \%$ with significant impact on students' engagement with $\mathrm{p}=$ 0.002. The factors that have most significant impact on students' engagement are classroom comfort $(\beta=-.114)$, classroom ambience $(\beta=.190)$, classroom safety $(\beta=$ -.163 and Position \& Visibility of White/Chalkboard ( $\beta$ $=.093)$.

Summarily, Figure 1 shows the overall impact of the physical learning environment of classrooms on students' learning outcomes

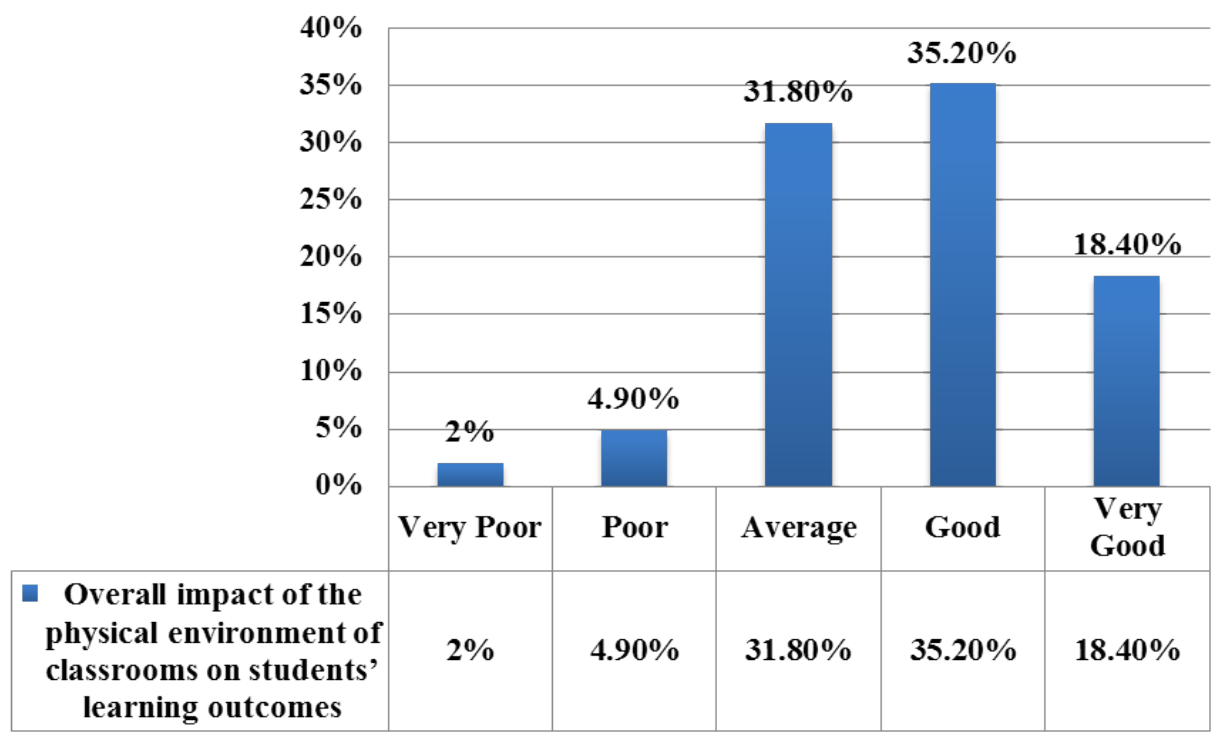

Figure 1. Overall impact of the physical learning environment of classrooms on students' learning outcomes 


\section{Conclusions}

This study has established that the classroom physical learning environment has a substantial impact on students' learning outcomes. Findings from this study will get stakeholders and school administrators thinking to consider schools and classroom environment as agents of socialisation for the holistic development of learners and not just an academic centre for assessment. This study makes contribution to knowledge by identifying aspects architects, interior designers, space planners and other stakeholders in educational planning and design should give adequate attention, in ensuring that classroom physical environments support affective, behavioural and cognitive learning outcomes of students. The findings of this research will also serve as feedback on the strategies for remodeling the existing classroom spaces to improve all aspects of the learning outcomes.

Furthermore, it has identified the factors to consider in remodeling classroom learning spaces in order to impact the three domains of students' learning outcomes. These factors are classroom comfort, classroom ambience, classroom geometry, classroom safety, ICT enabled classroom, classroom acoustics, classroom furniture, classroom visibility \& outdoor views, obstruction to classroom lighting \& ventilation, classroom density and position \& visibility of white/chalkboard as shown in Table 2.

As a result of these factors, a combined proportion of $53.6 \%$ of respondents experienced a significant impact of the classroom physical learning environment on their learning outcomes. 31.8\% affirmed to its average impact while only $6.9 \%$ averred to its least impact respectively.

This study was limited to the senior secondary cadre of schooling and further studies can explore other cadres in the study area.

\section{Abbreviations and Acronyms}

SDG - Sustainable Development Goals

ABCs of learning - Affective, Behavioural and Cognitive development of learners.

PCA - Principal Component Analysis

CATREG - Categorical Regression

\section{Acknowledgments}

The authors would like to appreciate Covenant University Centre for Research, Innovation and Discovery (CUCRID) for the support for this publication. We appreciate Dr. Tosin Babalola and the sampled schools for the opportunity to undertake this study in their respective schools.

\section{REFERENCES}

[1] Tanner, C. K. (2000). The influence of school architecture on academic achievement. Journal of educational administration, 38(4), 309-330.

[2] Obayan, P. T. (2003). Realizing Nigerian millennium education dream. The UBE in O. Bamisaiye, Nwazuoke and Okediran (eds). Education this Millennium, Ibadan.

[3] Edwards, L., \& Torcellini, P. (2002). Literature review of the effects of natural light on building occupants (No. NREL/TP-550-30769). National Renewable Energy Lab., Golden, CO.(US).

[4] Klatte, M., Bergström, K., \& Lachmann, T. (2013). Does noise affect learning? A short review on noise effects on cognitive performance in children. Frontiers in Psychology, 4: 578-589.

[5] Wannarka, R., \& Ruhl, K. (2008). Seating arrangements that promote positive academic and behavioural outcomes: A review of empirical research. Support for learning, 23(2), 89-93.

[6] Bakó-Biró, Z., Clements-Croome, D. J., Kochhar, N., Awbi, H. B., \& Williams, M. J. (2012). Ventilation rates in schools and pupils' performance. Building and Environment, 48: 215-223.

[7] Maxwell, L. E. (2003). Home and school density effects on elementary school children: The role of spatial density. Environment and Behavior, 35(4), 566-578.

[8] Woolner, P., \& Hall, E. (2010). Noise in schools: a holistic approach to the issue. International journal of environmental research and public health, 7(8), 3255-3269.

[9] Jonathan A. Odukoya, David O. Omole, Aaron A. Atayero, Joke A. Badejo, Segun I. Popoola, Temitope M. John \& Emeka Ucheaga | (2018) Learning attributes of summa cum laude students: Experience of a Nigerian university, Cogent Education, 5:1, 1426675

[10] Al-Enezi, M. M. (2002). A study of the relationship between school building Conditions and academic achievement of twelfth grade students in Kuwaiti public high schools. Unpublished $\mathrm{PhD}$ thesis. America: The Virginia Polytechnic Institute and State University.

[11] Amirul, N. J., Ahmad, C. N., Yahya, A. F., Abdullah, M., Noh, N. M., \& Adnan, M. (2013). The physical classroom learning environment. In Proceedings of the International Higher Education Teaching and Learning Conference, 2(1), 1-9.

[12] Chickering, A. W. \& E. F. Gamson, (1987). Seven Principles for Good Practice in Undergraduate Education. American Association of Higher Education (AAHE), Bulletin 39 (7), 3-7.

[13] Anekwe, J. U. (2006). "Effects of Constructivist-Based Instructional Model on Students 'Interest and Academic Achievement in French language in Anambra State." Unpublished $\mathrm{PhD}$ Thesis. University of Port-Harcourt Rivers State 
[14] Ibem E., Alagbe O., Owoseni A. (2017). A Study of Students' Perception of the Learning Environment: Case Study of Department of Architecture, Covenant University, Ota Ogun State, Inted2017 Proceedings, 6275-6286.

[15] Izobo-Martins, O., Dare-Abel, O. A., \& Ayo-Vaughan, K. (2014). Infrastructure Conditions in Public Secondary Schools, Ogun State, Nigeria. Journal of Civil, Structural, Environmental and Infrastructure Engineering Research and Development, 4(5): 17-25.

[16] Watkins C., Carnell E., Lodge C, Wagner P. \&Whalley C.
(2002) Effective Learning. Retrieved on 13 June 2018, from: https://www.researchgate.net/ publication/32019502 7_Effective_Learning

[17] Blackmore, J., Bateman, D., O’Mara, J., Loughlin, J., \& Aranda, G. (2011). The connections between learning spaces and learning outcomes: People and learning places. Retrieved 12 March 2018, from Learning Spaces: http://www. learning spaces. edu.au/docs/learningspaces-li terature-review. pdf.M. Young, The Techincal Writers Handbook. Mill Valley, CA: University Science, 1989. 